\title{
Influence of Initial Aerobic Decomposition on Vermicomposting of Paper Mill Wastes Amended with Saw Dust and Cow Dung
}

\author{
Devjani Mohapatra, Sahoo KK and AK Sannigrahi*
}

Department of Chemistry, Fakir Mohan (Autonomous) College, Proof Road, Balasore, Odisha, India

\begin{abstract}
Paper mill wastes, though a hazardous wastes due to presence of different heavy metals, attract attention of researchers due to its huge availability as unwanted products, presence of good quantity of organic materials and society's concern on environment pollution. Structural and Nitrogen amendments of Paper mill wastes are basic necessity at the initial decomposition stage for making it palatable to earthworms as well as for effective vermicomposting. This experiment was conducted for finding out the requirement of minimum possible time for initial aerobic decomposition of waste paper based paper mill wastes amended with saw dust and cow dung, either alone or in combination during its vermicomposting using Eisenia fetida earthworms. It was found that the amendment of Paper Mill waste with saw dust and cow dung in 1:0.5:0.5 ratio when processed through initial aerobic decomposition at least for 14 days with two turnings at 7 days interval, became very suitable for growth and survivability of earthworms and produced nutrient rich best quality vermicomposts which ultimately supported good growth of paddy seedlings. More turnings of bed materials help to reduce the concentration of heavy metals in vermicomposts through leaching loss. Addition of saw dust and cow dung as structural amendments with paper mill wastes increases both primary and secondary nutrients in vermicomposts prepared using Eisenia fetida earthworms.
\end{abstract}

Keywords: Aerobic decomposition; Cow dung; Eisenia fetida; Paper mill wastes; Saw dust; Vermicomposting

\section{Introduction}

Paper industry is one of the highest polluting industries in India and is highly water intensive. Paper mill sludge is inevitable waste product of the paper making process. Although many paper mills have started incineration of their wastes for energy recovery, a substantial amount (about 70\%) of these solid wastes (by-products) are still dumped or spread directly on land [1]. Keeping in view of high percentage of organic matter present in paper mill wastes, numbers of researchers have concentrated their efforts towards developing potential applications for this solid paper mill wastes [2]. Vermicomposting using epigeic earthworms is an eco-biotechnological process that transforms energy rich and complex organic substances into a stabilized vermicomposts. Researchers have used different organic materials as structural and nitrogen amendments of paper mill wastes for its successful composting or vermicomposting e.g. fruit and vegetable wastes by Tucker [3], saw dust by Thyagarajan et al. [4], food processing industry's wastes by Quintern [5], mixture of Agricultural, municipal solid wastes and poultry wastes by Yadav and Madan [1], Leaf litter and cow dung by Ponmani et al. [6], mixture of Pig wastes, water hyacinth and cow dung by Natarajan and Gajendran [7], etc. Earthworms generally consume half decomposed organic wastes and initial aerobic composting plays an important role to provide palatable food for earthworms. Sannigrahi and Sannigrahi [8] showed that two stage composting technique i.e., initial aerobic composting for about a month in open space followed by vermicomposting under shade was the best techniques for rapid vermicomposting of different organic wastes. Decomposition as well as vermicomposting no doubt depends on nature of substrates or waste materials. Vermicomposting was found quicker (within 1 to 2.5 months) in case of soft organic wastes like residues/leaves of vegetable plants, aquatic plants and soft weeds; moderate ( 3 to 4.5 months) in case of residues of cereal crops while slow (5 to 10 months) in case of dry leaves of trees [9]. The Paper Mill at Balasore is producing 100 tons of paper per day from waste papers and generating a huge quantity of Paper mill wastes, majority of which is dumped by the side of effluent channel, thus polluting soil and water and hampering growth of crops in nearby fields. Keeping all these in view this experiment was conducted to confirm the suitable saw dust cow dung ratio for quick vermicomposting of waste paper based paper mill wastes and also to find out the minimum possible time for initial aerobic decomposition of amended paper mill waste for making it palatable to released earthworms.

\section{Material and Methods}

Paper Mill waste (PMW) after collection from the dump yard of Paper Mill situated by the side of Effluent release channel (Swapna nalla), dried in sheds and powdered for conducting experiment. PMW was almost neutral in reaction $(\mathrm{pH} 7.65)$ with electrical conductivity $3.0 \mathrm{dS} / \mathrm{m}$ and contained $1.14 \%$ total N, $0.24 \%$ total $\mathrm{P}, 0.65 \%$ total $\mathrm{K}$ and $\mathrm{C} / \mathrm{N}$ ratio 27.6. Saw dust was collected from nearby Saw Mill. Its $\mathrm{pH}$ (1:2) was 7.49 and EC $0.4 \mathrm{dS} / \mathrm{m}$ while total $\mathrm{N}, \mathrm{P}$ and $\mathrm{K}$ were $0.89 \%$, $0.48 \%$ and $0.54 \%$. Cow dung having $\mathrm{pH}(1: 2) 7.23$, EC $0.80 \mathrm{dS} / \mathrm{m}$, Total $\mathrm{N} 0.35 \%$, Total P $0.29 \%$ and Total K $0.38 \%$ was collected from local cow shed. The experiment was conducted during February to April 2016 in rectangular plastic trays of capacity $2 \mathrm{~kg}$. The PMW was amended with saw dust and cow dung mixed in three different ratios i.e., $1 \mathrm{~kg}$ : $1 \mathrm{~kg}: 0 \mathrm{~kg}\left(\mathrm{~T}_{1}\right), 1 \mathrm{~kg}: 0.5 \mathrm{~kg}: 0.5 \mathrm{~kg}\left(\mathrm{~T}_{2}\right)$ and $1 \mathrm{~kg}: 0 \mathrm{~kg}: 1 \mathrm{~kg}\left(\mathrm{~T}_{3}\right)$ for making experimental beddings of $2 \mathrm{~kg}$ each. Sufficient water is added to make each bed moist. Nine beds were made for each treatment which ultimately separated in three sets $\left(\mathrm{D}_{7}, \mathrm{D}_{14}\right.$ and $\left.\mathrm{D}_{21}\right)$. All trays were arranged on racks inside the laboratory at room temperature after covering each tray with hessian cloths (Figure 1).

*Corresponding author: AK Sannigrahi, Department of Chemistry, Fakir Mohan (Autonomous) College, Proof Road, Balasore, Odisha 756 025, India, Tel: +91 6782-272192; Fax: +91 6782-272126; E-mail: sannigrahi_ak@rediffmail.com

Received January 15, 2018; Accepted January 30, 2018; Published February 06, 2018

Citation: Mohapatra D, Sahoo KK, Sannigrahi AK (2018) Influence of Initial Aerobic Decomposition on Vermicomposting of Paper Mill Wastes Amended with Saw Dust and Cow Dung. Int J Waste Resour 8: 325. doi: 10.4172/2252-5211.1000325

Copyright: (c) 2018 Mohapatra D, et al. This is an open-access article distributed under the terms of the Creative Commons Attribution License, which permits unrestricted use, distribution, and reproduction in any medium, provided the original author and source are credited. 
Citation: Mohapatra D, Sahoo KK, Sannigrahi AK (2018) Influence of Initial Aerobic Decomposition on Vermicomposting of Paper Mill Wastes Amended with Saw Dust and Cow Dung. Int J Waste Resour 8: 325. doi: 10.4172/2252-5211.1000325

In first set $\left(D_{7}\right) 20$ healthy adult Eisenia fetida earthworms were released on top of each bed after thoroughly mixing the bedding materials of each tray on $7^{\text {th }}$ day and trays were covered again with moist hessian cloths. In second set $\left(\mathrm{D}_{14}\right) 20$ healthy adult Eisenia fetida earthworms were released on top of each tray on $14^{\text {th }}$ day after mixing bedding materials of each tray twice i.e., on $7^{\text {th }}$ and $14^{\text {th }}$ day and covered always with moist hessian cloths for maintaining a moist environment. Similarly in third set $\left(D_{21}\right)$ all trays were thoroughly mixed thrice i.e., on $7^{\text {th }}, 14^{\text {th }}$ and $21^{\text {st }}$ day and 20 healthy adult earthworms were released on top of each tray on $21^{\text {st }}$ day and kept in similar ways under the cover of hessian cloths. Regular monitoring was done to maintain 70 to $80 \%$ moisture by spraying of water time to time as and when required and also to protect earthworms from predators like frogs, ants etc. After 45 days when composting material became black coloured loosely granular structured material, the bed materials were spread on the floor under the shade for separating earthworms through hand sorting and also for partial air drying. Vermicompost of each treatment was sieved separately through $2 \mathrm{~mm}$ sieve (Figure 2) and kept in plastic zipper bags. To determine the nutrient status of these vermicomposts different chemical analysis were done following standard methods [10]. Heavy metal contents were analysed in Testing and research laboratory for water, soil and food products of Environmental Monitoring Service, Aurobrindavan, Auroville, Puduchery from diacid digested extracts using Atomic Adsorption Spectrometer. Results were calculated on oven dry basis and analysed statistically.

Efficacy of those vermicomposts on growth of paddy seedlings was studied in pot culture. Vermicomposts at the rate of $12 \mathrm{~g} /$ pot was mixed with $48 \mathrm{~g}$ sand taken in plastic pots of $100 \mathrm{ml}$ capacity in triplicate and kept in randomized block design. Ten paddy seeds (Oryza sativa) were placed on each pot and water was added to submerge seeds. Experiment on plastic pot is shown in Figure 3. After 15 days seedlings were taken out of sand beds, washed thoroughly to remove sands and put on blotting papers to soak out excess water attached to seedlings. Plant weight was measured in electronic weighing machine. Shoot length and root length were measured for each seedling. Seedlings were kept in oven for overnight drying at $100^{\circ} \mathrm{C}$. Dry weight of all seedlings of each pot was measured together. Average results were calculated.

\section{Results and Discussion}

\section{Vermicomposts and growth of earthworms}

The quantity of vermicomposts prepared from Paper mill wastes amended with saw dust and cow dung in different ratio, percentage

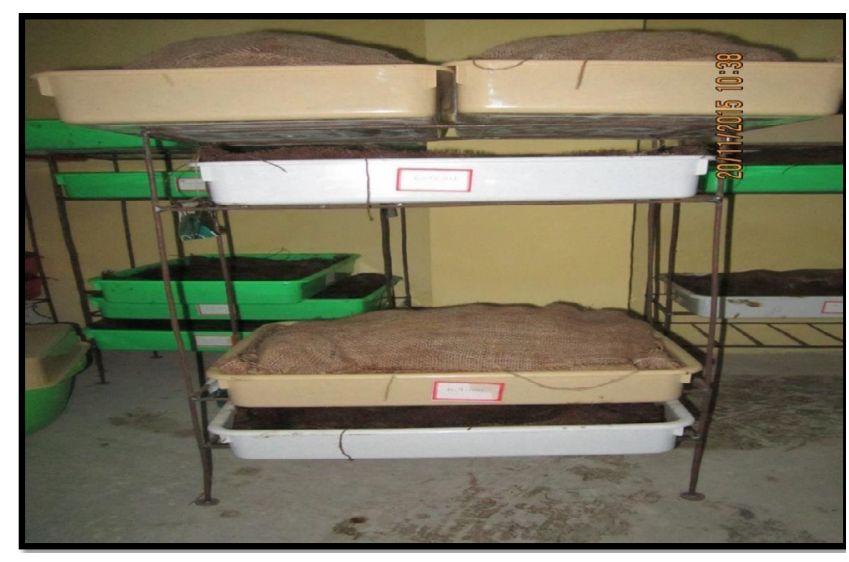

Figure 1: Arrangement of vermicomposting trays on iron racks. of non-composted portion and data on earthworms harvested after completion of experiment are presented in Table 1. Impact of turning of substrates as well as composition of substrates on vermicompost production is clearly visible. Among the three treatments even though vermicompost production was found comparatively more in treatment $\mathrm{T}_{1}$ of all three sets, but comparing the percentage of non-composting portion, performance of $\mathrm{T}_{2}$ i.e., mixture of $\mathrm{PMW}, \mathrm{SD}$ and $\mathrm{CD}$ in ratio 1:0.5:0.5 was found always better as it was balanced with saw dust and cow dung amendments. Cow dung helped as good starter feed for earthworms and saw dust, being finer, quickly decomposed and became food for earthworms. The result as given in Table 1 clearly showed that addition of earthworm after 7 days and one turning could produce about $35 \%$ vermicompost while yield increased to about $45 \%$ and $49 \%$ when earthworms were added after 14 days and two turnings and after 21 days and three turnings. It is obvious since more turnings to bed materials before earthworm addition gave better performance in all three treatments due to creation of favorable environment to earthworms with better decomposition of bed materials with time and turnings. The cow dung as structural amendment alone for vermicomposting of PMW was not found encouraging since the quantity of vermicompost was very less, non-composted portion was comparatively more and numbers of earthworms were also less. The less numbers of juveniles proved that earthworms could not multiply much in this composition

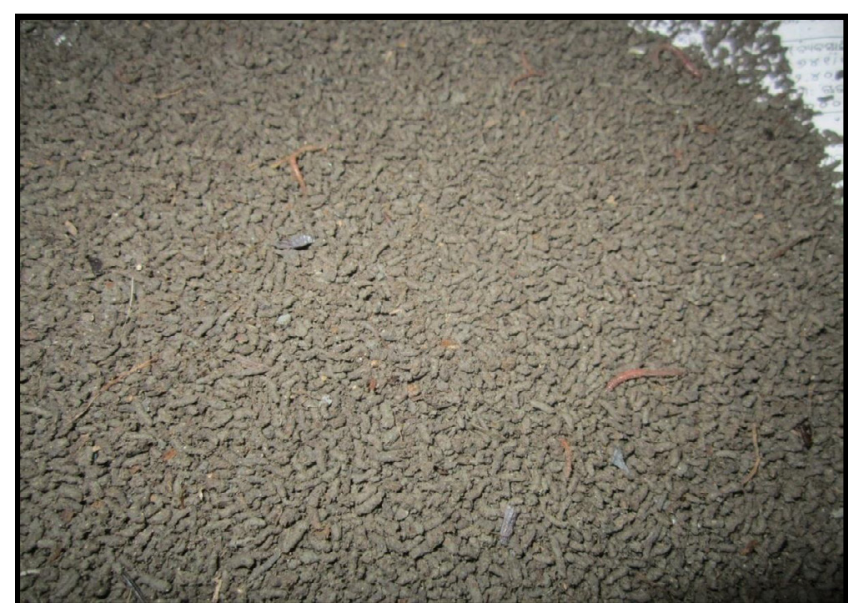

Figure 2: Vermicomposts prepared from saw dust-cow dung amended PMW.

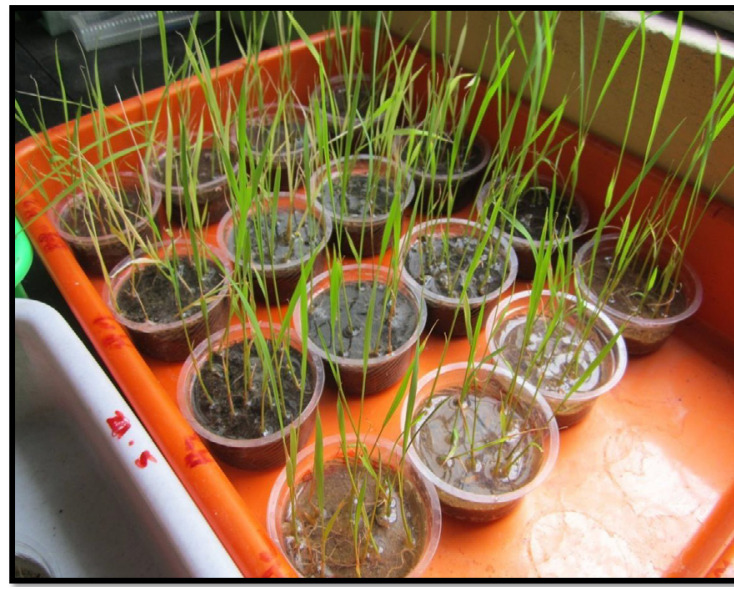

Figure 3: Growth of paddy seedlings in sand with vermicomposts. 


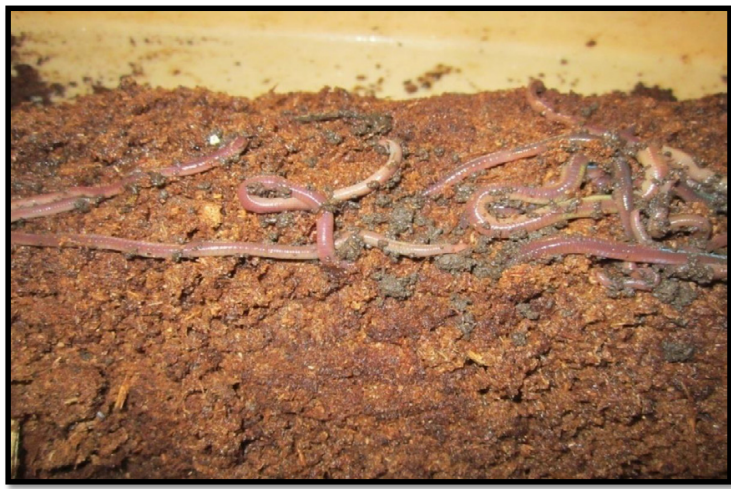

Figure 4: Earthworms enjoying paper mill wastes amended with cow dung and saw dust.

might be due to rapid loss of moisture from PMW - CD mixture, thus making the bed comparatively hard and also the release of some unfavourable chemicals or salt from PMW in presence of cow dung, together which made the medium not much favourable for growth of earthworms. Highest numbers of earthworm (both big and small) were recorded in treatment $T_{2}$ where amendment of paper mill wastes was carried out with saw dust and cow dung combination which created the condition of better decomposition of feeding materials under better airy and moist environment.

The availability of more number of adult and juvenile earthworms during vermicomposting of PMW with both cow dung and saw dust in $\mathrm{T}_{2}$ of second set i.e., release of earthworms on $14^{\text {th }}$ day after two times turnings of bed materials at 7 days interval suggested that this condition is more favourable to growth of Eisenia fetida earthworms (Figure 4). As suggested earlier this might be due to availability of better airy and moist environment for growth and palatable feed for earthworms in this particular combination than other treatments. Beneficial impact of saw dust in co-composting of pulp and paper mill sludge in 3:1 ratio in presence of cow dung and effective microorganism was also reported by Thyagarajan et al. [4].

\section{Chemical analysis of vermicomposts}

Data presented in Table 2 showed that the $\mathrm{pH}$ of vermicomposts varied from 7.09 to 8.37 , indicating considerable variation in $\mathrm{pH}$ when PMW was amended with cow dung and saw dust in different ratio. Addition of cow dung kept the $\mathrm{pH}$ little lower in comparison to saw dust alone confirming earlier opinion of release of organic acid from cow dung during its decomposition. More turnings of bed materials not only helped in better decomposition of substrates but also facilitate to release out of more chemicals/salts from the beds and to reduce the $\mathrm{pH}$ of vermicomposts processed by Eisenia fetida.

Electrical conductivity (EC) of vermicomposts prepared in different treatments varied from 0.63 to $2.53 \mathrm{dS} / \mathrm{m}$. Replacement of saw dust with cow dung in the bed materials increased the EC which was obvious as EC of original Cow dung measured as $0.80 \mathrm{dS} / \mathrm{m}$ while that of Saw dust was $0.40 \mathrm{dS} / \mathrm{m}$. Lowering in EC of vermicomposts prepared from bed materials turned more than once might be due to loss of salt through leaching out of beds after its dissolution with acidic materials formed with more decomposition with time and turnings.

The total moisture percentage of processed vermicomposts was ranged between 33.17 to 54.58 percent, indicating well maintenance of moisture by vermicomposts. The vermicomposts prepared from PMW amended with both saw dust and cow dung hold little higher moisture than others. Turning did not show any particular trend in relation to moisture content.

Amendment of Paper Mill waste with CD and SD showed considerable variation even in oxidizable organic carbon content of processed vermicomposts (Table 2), ranging from lowest $4.69 \%$ recorded in PMW amended with SD with three turnings ( $\mathrm{T}_{1}$ of $3^{\text {rd }}$ set) to highest $14.33 \%$ recorded in similar treatment $\left(\mathrm{T}_{1}\right)$ of 1 st set where bed materials turned once only at 7 days. More turnings helped in loss of organic carbon due to more decomposition of bed materials. Vermicomposting always helps to reduce $\mathrm{C} / \mathrm{N}$ ratio of the bedding materials by reducing the carbon content with maturity.

The chemical analysis data presented in Table 3 clearly showed that addition of cow dung with saw dust as structural amendment with waste paper based Paper Mill wastes changed differently the macro nutrient status of vermicomposts processed by Eisenia fetida. Total nitrogen contents, varying from 0.69 to $1.19 \%$, was always found more in vermicomposts prepared from PMW amended with saw dust only. Similar result was also recorded earlier by Thyagarajan et al. [4]. Addition of more cow dung asamendment by replacing saw dust generally recorded slight lesser nitrogen, probably due to less nitrogen present in cow dung in comparison to saw dust. Turning of bed materials helped more in its microbial decomposition and also in vermicomposting, thus increasing total nitrogen of vermicompost in treatments with more turning. Total phosphorus content ranging from 0.14 to $0.32 \%$, on the other hand, showed considerable difference among treatments in first set but the difference was narrowed down with more turnings or decomposition (Table 3). This results confirmed the earlier findings of researchers (1, 3 and 4), who also recorded comparatively more phosphorus in vermicomposts prepared from PMW - saw dust amendment than that from PMW - cow dung amendment. Little less phosphorus with more turnings might be due to more adsorption of phosphorus in Earthworm body tissue. In $2^{\text {nd }}$ and $3^{\text {rd }}$ sets, Treatment $\mathrm{T}_{2}$ recorded slight higher total phosphorus indicating beneficial impact of turnings of bed materials.

Total potassium content ( 0.36 to $0.80 \%$ ), however, showed different trend. In $1^{\text {st }}$ set with one turning vermicompost from cow dung amended PMW recorded little more potassium while in $2^{\text {nd }}$ and $3^{\text {rd }}$ sets with more turnings vermicomposts from saw dust - cow dung amended PMW recorded better potassium contents than that of others (Table 3). Comparatively lesser content of total potassium in third turnings of bed materials strengthen earlier suggestion that there might be some leaching loss of mobile potassium from beds during more turnings.

Table 4 presented data on total calcium, sulfur and sodium contents recorded in vermicomposts prepare from PMW amended with different quantities of saw dust and cow dung. Total calcium ranging from 5.88 to $8.58 \%$, increased with addition of cow dung but the amount showed a decreasing trend with turnings. Total sulfur content varied from 0.19 to $0.34 \%$ and similar to calcium content, sulfur content also increased in presence of cow dung but impacts of turnings was found different. During second turning of bed materials sulfur content though increased but decreased slightly in third turnings. Total sodium content ( 0.17 to $0.37 \%)$ also recorded slight increase with addition of cow dung but its decrease was quite considerable in case of $3^{\text {rd }}$ turnings. Loss of secondary nutrients in $3^{\text {rd }}$ turnings of bed materials confirms the earlier suggestion of leaching loss of salts from beds with turnings.

Presence of total chromium and lead, being major problem in wastes of waste paper based Paper mills, were analyzed along with 
Citation: Mohapatra D, Sahoo KK, Sannigrahi AK (2018) Influence of Initial Aerobic Decomposition on Vermicomposting of Paper Mill Wastes Amended with Saw Dust and Cow Dung. Int J Waste Resour 8: 325. doi: 10.4172/2252-5211.1000325

Page 4 of 6

\begin{tabular}{|c|c|c|c|c|c|c|}
\hline \multirow{2}{*}{$\begin{array}{l}\text { Set } \\
\text { No. }\end{array}$} & \multirow{2}{*}{$\begin{array}{c}\text { Treat } \\
\text { ment No. }\end{array}$} & \multirow{2}{*}{$\begin{array}{c}\text { Raw material mixture } \\
\text { PMW + SD + CD } \\
(\mathbf{k g})\end{array}$} & \multirow{2}{*}{$\begin{array}{l}\text { Vermicompost harvested } \\
(\mathbf{k g})\end{array}$} & \multirow{2}{*}{$\begin{array}{l}\text { Non- composted } \\
\text { Portion (\%) }\end{array}$} & \multicolumn{2}{|c|}{ Earthworms harvested } \\
\hline & & & & & $\begin{array}{l}\text { Nos. (Big + } \\
\text { Small) }\end{array}$ & $\begin{array}{c}\text { Total } \\
\text { weight (g) }\end{array}$ \\
\hline \multirow{3}{*}{$\mathrm{D}_{7}$} & $\mathrm{~T}_{1}$ & $1+1+0$ & $0.97 \pm 0.10$ & $17.9 \pm 3.8$ & $16+100$ & 40 \\
\hline & $\mathrm{T}_{2}$ & $1+0.5+0.5$ & $0.74 \pm 0.10$ & $17.3 \pm 3.4$ & $20+100$ & 50 \\
\hline & $\mathrm{T}_{3}$ & $1+0+1$ & $0.42 \pm 0.07$ & $31.3 \pm 1.2$ & $15+50$ & 20 \\
\hline \multirow{3}{*}{$\mathrm{D}_{14}$} & $\mathrm{~T}_{1}$ & $1+1+0$ & $1.25 \pm 0.10$ & $15.3 \pm 5.9$ & $20+100$ & 48 \\
\hline & $\mathrm{T}_{2}$ & $1+0.5+0.5$ & $0.96 \pm 0.17$ & $11.9 \pm 4.0$ & $24+300$ & 78 \\
\hline & $\mathrm{T}_{3}$ & $1+0+1$ & $0.52 \pm 0.13$ & $26.9 \pm 4.4$ & $17+75$ & 40 \\
\hline \multirow{3}{*}{$\mathrm{D}_{21}$} & $\mathrm{~T}_{1}$ & $1+1+0$ & $1.40 \pm 0.14$ & $13.7 \pm 1.1$ & $22+150$ & 50 \\
\hline & $\mathrm{T}_{2}$ & $1+0.5+0.5$ & $0.86 \pm 0.19$ & $12.0 \pm 3.1$ & $23+250$ & 60 \\
\hline & $\mathrm{T}_{3}$ & $1+0+1$ & $0.67 \pm 0.13$ & $21.0 \pm 3.5$ & $19+50$ & 42 \\
\hline
\end{tabular}

Table 1: Production of vermicomposts from paper mill wastes amended with SD and CD.

\begin{tabular}{|c|c|c|c|c|c|c|}
\hline $\begin{array}{l}\text { Set } \\
\text { No. }\end{array}$ & $\begin{array}{c}\text { Treat } \\
\text { ment } \\
\text { No. }\end{array}$ & $\begin{array}{c}\text { Raw material } \\
\text { mixture PMW + } \\
\text { SD + CD } \\
(\mathbf{k g})\end{array}$ & $\mathrm{P}^{\mathrm{H}}(\mathbf{1}: 2)$ & $\mathrm{EC}(\mathrm{dS} / \mathrm{m})$ & Moisture (\%) & $\begin{array}{l}\text { Oxidizable organic Carbon } \\
(\%)\end{array}$ \\
\hline \multirow{3}{*}{$\mathrm{D}_{7}$} & $\mathrm{~T}_{1}$ & $1+1+0$ & $8.31 \pm 0.07$ & $0.85+0.15$ & $33.17 \pm 10.56$ & $14.33 \pm 0.44$ \\
\hline & $\mathrm{T}_{2}$ & $1+0.5+0.5$ & $7.85 \pm 0.04$ & $1.80+0.10$ & $40.00 \pm 11.14$ & $13.95 \pm 2.34$ \\
\hline & $\mathrm{T}_{3}$ & $1+0+1$ & $7.09 \pm 0.05$ & $2.53+0.21$ & $31.67 \pm 6.81$ & $9.77 \pm 3.28$ \\
\hline \multirow{3}{*}{$D_{14}$} & $\mathrm{~T}_{1}$ & $1+1+0$ & $8.17 \pm 0.18$ & $0.73+0.21$ & $47.27 \pm 14.68$ & $5.45 \pm 2.88$ \\
\hline & $\mathrm{T}_{2}$ & $1+0.5+0.5$ & $7.45 \pm 0.11$ & $1.27+0.15$ & $54.58 \pm 16.32$ & $6.97 \pm 5.97$ \\
\hline & $\mathrm{T}_{3}$ & $1+0+1$ & $7.40 \pm 0.10$ & $1.97+0.15$ & $40.17 \pm 20.42$ & $7.10 \pm 3.07$ \\
\hline \multirow{3}{*}{$\mathrm{D}_{21}$} & $\mathrm{~T}_{1}$ & $1+1+0$ & $8.03 \pm 0.01$ & $0.63+0.06$ & $47.90 \pm 5.35$ & $4.69 \pm 10.2$ \\
\hline & $\mathrm{T}_{2}$ & $1+0.5+0.5$ & $7.55 \pm 0.13$ & $1.23+0.15$ & $52.24 \pm 13.49$ & $8.75 \pm 1.74$ \\
\hline & $\mathrm{T}_{3}$ & $1+0+1$ & $7.30 \pm 0.11$ & $1.87+0.15$ & $43.67 \pm 12.85$ & $9.15 \pm 6.94$ \\
\hline
\end{tabular}

Table 2: Physico - chemical characteristics ( $\mathrm{pH}, \mathrm{EC}$, Oxidizable organic carbon and moisture content) of processed vermicomposts.

\begin{tabular}{|c|c|c|c|c|c|}
\hline $\begin{array}{l}\text { Set } \\
\text { No. }\end{array}$ & $\begin{array}{l}\text { Treat } \\
\text { ment No. }\end{array}$ & $\begin{array}{c}\text { Raw material mixture } P M W+S D+C D \\
(\mathbf{k g})\end{array}$ & Total N (\%) & Total P (\%) & Total K (\%) \\
\hline \multirow{3}{*}{$\mathrm{D}_{7}$} & $\mathrm{~T}_{1}$ & $1+1+0$ & $0.87 \pm 0.47$ & $0.29 \pm 0.02$ & $0.59 \pm 0.08$ \\
\hline & $\mathrm{T}_{2}$ & $1+0.5+0.5$ & $0.84 \pm 0.03$ & $0.22 \pm 0.02$ & $0.66 \pm 0.04$ \\
\hline & $\mathrm{T}_{3}$ & $1+0+1$ & $0.69 \pm 0.43$ & $0.14 \pm 0.01$ & $0.80 \pm 0.04$ \\
\hline \multirow{3}{*}{$D_{14}$} & $\mathrm{~T}_{1}$ & $1+1+0$ & $1.17 \pm 0.28$ & $0.29 \pm 0.02$ & $0.78 \pm 0.07$ \\
\hline & $\mathrm{T}_{2}$ & $1+0.5+0.5$ & $1.03 \pm 0.23$ & $0.32 \pm 0.02$ & $0.84 \pm 0.03$ \\
\hline & $\mathrm{T}_{3}$ & $1+0+1$ & $0.85 \pm 0.35$ & $0.25 \pm 0.01$ & $0.76 \pm 0.15$ \\
\hline \multirow{3}{*}{$\mathrm{D}_{21}$} & $\mathrm{~T}_{1}$ & $1+1+0$ & $1.19 \pm 0.09$ & $0.23 \pm 0.01$ & $0.66 \pm 0.11$ \\
\hline & $\mathrm{T}_{2}$ & $1+0.5+0.5$ & $1.09 \pm 0.15$ & $0.25 \pm 0.02$ & $0.70 \pm 0.03$ \\
\hline & $\mathrm{T}_{3}$ & $1+0+1$ & $0.94 \pm 0.16$ & $0.20 \pm 0.01$ & $0.64 \pm 0.04$ \\
\hline
\end{tabular}

Table 3: Macro nutrient status in vermicomposts.

\begin{tabular}{|c|c|c|c|c|c|}
\hline $\begin{array}{l}\text { Set } \\
\text { No. }\end{array}$ & $\begin{array}{c}\text { Treat } \\
\text { ment } \\
\text { No. }\end{array}$ & $\begin{array}{c}\text { Raw material mixture } P M W \\
(\mathrm{~kg})\end{array}$ & Total Ca (\%) & Total S (\%) & Total Na (\%) \\
\hline \multirow{3}{*}{$D_{7}$} & $\mathrm{~T}_{1}$ & $1+1+0$ & $6.60 \pm 1.09$ & $0.21 \pm 0.03$ & $0.23 \pm 0.02$ \\
\hline & $\mathrm{T}_{2}$ & $1+0.5+0.5$ & $8.16 \pm 1.60$ & $0.26 \pm 0.02$ & $0.32 \pm 0.01$ \\
\hline & $T_{3}$ & $1+0+1$ & $8.58 \pm 1.05$ & $0.28 \pm 0.04$ & $0.32 \pm 0.02$ \\
\hline \multirow{3}{*}{$D_{14}$} & $T_{1}$ & $1+1+0$ & $6.29 \pm 1.19$ & $0.24 \pm 0.10$ & $0.23 \pm 0.06$ \\
\hline & $\mathrm{T}_{2}$ & $1+0.5+0.5$ & $8.28 \pm 0.65$ & $0.33 \pm 0.01$ & $0.33 \pm 0.03$ \\
\hline & $\mathrm{T}_{3}$ & $1+0+1$ & $7.20 \pm 1.74$ & $0.34 \pm 0.07$ & $0.37 \pm 0.02$ \\
\hline \multirow{3}{*}{$D_{21}$} & $T_{1}$ & $1+1+0$ & $5.88 \pm 0.27$ & $0.19 \pm 0.03$ & $0.17 \pm 0.03$ \\
\hline & $\mathrm{T}_{2}$ & $1+0.5+0.5$ & $6.32 \pm 0.64$ & $0.26 \pm 0.04$ & $0.25 \pm 0.03$ \\
\hline & $\mathrm{T}_{3}$ & $1+0+1$ & $7.02 \pm 0.65$ & $0.27 \pm 0.05$ & $0.26 \pm 0.04$ \\
\hline
\end{tabular}

Table 4: Calcium, sulphur and sodium status of vermicomposts.

total zinc from vermicomposts prepared from saw dust and cow dung amended Paper mill wastes of Emami paper mills. Total $\mathrm{Cr}, \mathrm{Pb}$ and $\mathrm{Zn}$ varied in those vermicomposts from 0.18 to $0.53 \%, 0.01$ to $0.51 \%$ and 0.03 to $1.58 \%$ respectively (Table 5 ). It was interesting to note that concentrations of these metals increased in presence of cow dung which probably not due to presence of more metals in cow dung but might be due to reaction of complex metallic contents of PMW with some acidic materials produced from cow dung. Slight increase in chromium and zinc contents after $2^{\text {nd }}$ turning confirmed their initial release in presence of cow dung. No clear trend was found in lead content. But 
Citation: Mohapatra D, Sahoo KK, Sannigrahi AK (2018) Influence of Initial Aerobic Decomposition on Vermicomposting of Paper Mill Wastes Amended with Saw Dust and Cow Dung. Int J Waste Resour 8: 325. doi: 10.4172/2252-5211.1000325

Page 5 of 6

\begin{tabular}{|c|c|c|c|c|c|}
\hline $\begin{array}{l}\text { Set } \\
\text { No. }\end{array}$ & $\begin{array}{c}\text { Treat } \\
\text { ment } \\
\text { No. }\end{array}$ & $\begin{array}{c}\text { Raw material mixture } P M W \\
(\mathrm{~kg})\end{array}$ & Total Cr (\%) & Total Pb (\%) & Total Zn (\%) \\
\hline \multirow{3}{*}{$D_{7}$} & $\mathrm{~T}_{1}$ & $1+1+0$ & $0.26 \pm 0.12$ & $0.38 \pm 0.09$ & $0.62 \pm 0.41$ \\
\hline & $\mathrm{T}_{2}$ & $1+0.5+0.5$ & $0.53 \pm 0.17$ & $0.25 \pm 0.13$ & $0.99 \pm 0.05$ \\
\hline & $\mathrm{T}_{3}$ & $1+0+1$ & $0.47 \pm 0.12$ & $0.51 \pm 0.15$ & $1.13 \pm 0.17$ \\
\hline \multirow{3}{*}{$D_{14}$} & $\mathrm{~T}_{1}$ & $1+1+0$ & $0.41 \pm 0.18$ & $0.35 \pm 0.11$ & $0.94 \pm 0.13$ \\
\hline & $\mathrm{T}_{2}$ & $1+0.5+0.5$ & $0.47 \pm 0.14$ & $0.38 \pm 0.13$ & $1.47 \pm 0.06$ \\
\hline & $\mathrm{T}_{3}$ & $1+0+1$ & $0.50 \pm 0.16$ & $0.41 \pm 0.06$ & $1.58 \pm 0.07$ \\
\hline \multirow{3}{*}{$D_{21}$} & $\mathrm{~T}_{1}$ & $1+1+0$ & $0.18 \pm 0.05$ & $0.01 \pm 0.02$ & $0.03 \pm 0.01$ \\
\hline & $\mathrm{T}_{2}$ & $1+0.5+0.5$ & $0.18 \pm 0.12$ & $0.02 \pm 0.01$ & $0.05 \pm 0.01$ \\
\hline & $\mathrm{T}_{3}$ & $1+0+1$ & $0.19 \pm 0.13$ & $0.07 \pm 0.12$ & $0.09 \pm 0.14$ \\
\hline
\end{tabular}

Table 5: Heavy metal contents in vermicomposts.

\begin{tabular}{|c|c|c|c|c|c|c|}
\hline \multirow[b]{2}{*}{$\begin{array}{l}\text { Set } \\
\text { No. }\end{array}$} & \multirow[b]{2}{*}{$\begin{array}{c}\text { Treat } \\
\text { ment No. }\end{array}$} & \multirow{2}{*}{$\begin{array}{c}\text { Raw material mixture } \\
\text { PMW + SD + CD } \\
(\mathbf{k g})\end{array}$} & \multirow[b]{2}{*}{ Shoot length $(\mathrm{cm})$} & \multirow[b]{2}{*}{ Root length $(\mathrm{cm})$} & \multicolumn{2}{|c|}{ Plant weight (g) } \\
\hline & & & & & $\begin{array}{c}\text { Fresh } \\
\text { weight }\end{array}$ & $\begin{array}{c}\text { Dry } \\
\text { weight }\end{array}$ \\
\hline \multirow{3}{*}{$\mathrm{D}_{7}$} & $\mathrm{~T}_{1}$ & $1+1+0$ & 16.09 & 7.54 & 1.30 & 0.26 \\
\hline & $\mathrm{T}_{2}$ & $1+0.5+0.5$ & 11.48 & 7.79 & 0.49 & 0.15 \\
\hline & $\mathrm{T}_{3}$ & $1+0+1$ & 10.53 & 7.25 & 0.98 & 0.21 \\
\hline \multirow{3}{*}{$D_{14}$} & $\mathrm{~T}_{1}$ & $1+1+0$ & 14.36 & 9.78 & 1.48 & 0.25 \\
\hline & $\mathrm{T}_{2}$ & $1+0.5+0.5$ & 20.50 & 10.56 & 1.60 & 0.50 \\
\hline & $\mathrm{T}_{3}$ & $1+0+1$ & 12.03 & 6.91 & 0.71 & 0.17 \\
\hline \multirow{3}{*}{$D_{21}$} & $\mathrm{~T}_{1}$ & $1+1+0$ & 12.24 & 8.80 & 1.50 & 0.25 \\
\hline & $\mathrm{T}_{2}$ & $1+0.5+0.5$ & 16.52 & 9.31 & 1.55 & 0.45 \\
\hline & $\mathrm{T}_{3}$ & $1+0+1$ & 11.06 & 5.58 & 1.02 & 0.22 \\
\hline
\end{tabular}

Table 6: Data on growth of paddy seedlings in vermicomposts.

quick decrease in concentrations of all the three metals to negligible amount after $3^{\text {rd }}$ turnings clearly points towards possible leaching loss of heavy metals released from PMW after mixing with water added during next turning. The quantity of each heavy metal recorded in these vermicomposts was, however, found within permissible limit and hence, not harmful to crops.

\section{Impact of vermicomposts on growth of paddy seedlings}

Vermicomposts prepared from PMW amended with cow dung and saw dust recorded good growth of paddy seedlings (Figure 3). Vermicompost prepared from $2^{\text {nd }}$ set i.e., after initial turnings of bed materials twice at 7 days interval and earthworm released on $14^{\text {th }}$ day performed better in seedling growths than vermicomposts of other sets, which was obvious since former vermicompost were significantly higher in their nutrient status in comparison to other combination (Table 6). Both shoot and root length of paddy seedlings varied from 10.53 to $20.50 \mathrm{~cm}$ and 5.58 to $10.56 \mathrm{~cm}$, respectively with highest result in $\mathrm{T}_{2}$ treatments of both $2^{\text {nd }}$ and $3^{\text {rd }}$ sets. Fresh and dry weight of seedlings ranging from 0.49 to $1.60 \mathrm{~g}$ and 0.15 to $0.50 \mathrm{~g}$ also showed similar pattern. In this experiment, the vermicomposts prepared from the mixture of PMW $(1 \mathrm{~kg})$ with $\mathrm{CD}(0.5 \mathrm{~kg})$ and $\mathrm{SD}(0.5 \mathrm{~kg})$ after initial aerobic composting for 14 days with two turnings of bed materials $\left(\mathrm{T}_{2}\right.$ of $2^{\text {nd }}$ set) gave best growth of paddy seedlings (average shoot length $20.5 \mathrm{~cm}$, average root length $-10.56 \mathrm{~cm}$, average weight of seedlings $1.60 \mathrm{~g}$ and dry weight of seedling $-0.50 \mathrm{~g}$ ). The performance on growth of seedlings supports the analytical data of different nutrients recorded in those vermicomposts.

\section{Conclusion}

The experiment, therefore, showed that along with structural amendment of PMW in different ratio, the initial aerobic decomposition also played an important role on vermicomposting as well as its nutrient quality. The amendment of Emami Paper Mill waste with saw dust and cow dung in 1:0.5:0.5 ratio along with initial aerobic composting for 14 days with twice turnings at 7 days interval was found very suitable for growth and survivability of earthworms, for production of nutrient rich vermicomposts and for growth of paddy seedlings. More turnings of bed materials at initial aerobic composting effectively reduce the concentration of heavy materials harmful for crop growth

\section{Acknowledgement}

The first author is thankful to the Principal, F M (A) College, Balasore for extending laboratory facility to carry out her research work.

\section{References}

1. Yadav A, Madan S (2013) Nutrient status of vermicompost of paper mill sludge with different wastes by using Eisenia fetida. Eur J Appl Sci 5: 62-66.

2. Elvira C, Sampedro L, Benitez E, Nogales R (1998) Vermicomposting of sludges from paper mill and dairy industries with Eisenia Andrei: A pilot scale study. Bioresour Technol 63: 205-211.

3. Tucker $P$ (2005) Co-composting paper mill sludge's with fruit and vegetable wastes. University of Paisley, Paisley, Scotland. pp: 1-168.

4. Thyagarajan LP, Meenambal T, Mangaleshwaran L, Lakshminarasimaiha N Ramesh N (2010) Recycling of pulp and paper industry sludge with saw dust by aerobic composting method. Nature Environment and Pollution Technology 9: 149-154.

5. Quintern M (2011) Organic waste free pulp mill through vermicomposting The Kinleith way. New Zealand Land Treatment Collective: Proceedings for the 2011 Annual Conference 32: 84-88

6. Ponmani S, Udayasoorian C, Jayabalakrishnan RM, Kumar KV (2014) Vermicomposting of paper mill solid waste using epigeic earthworm Eudrilus eugeniae. J Environ Biol 35: 617-622.

7. Natarajan N, Gajendran M (2014) Vermiconversion of paper mill sludge for recycling the nutrients using earthworm Eudrilus eugeniae. IOSR J Environ Sci Toxicol Food Technol 8: 6-11. 
Citation: Mohapatra D, Sahoo KK, Sannigrahi AK (2018) Influence of Initial Aerobic Decomposition on Vermicomposting of Paper Mill Wastes Amended with Saw Dust and Cow Dung. Int J Waste Resour 8: 325. doi: 10.4172/2252-5211.1000325

8. Sannigrahi AK, Sannigrahi D (2006) Two stage composting technique for rapid and beneficial utilization of farm wastes. Indian Farmers' Digest 39: 17-21.

9. Sannigrahi AK, Chakrabortty S (2002) Beneficial management of organic wastes by vermicomposting. Indian Journal of Environmental Protection 22 405-408.
10. Bhargava BS, Raghupati HB (1993) Analysis of plant materials for macro and micronutrients. In: Tandon HLS (ed.). Methods of Analysis of soils, plants, waters and fertilizers. Fertilizer Development and Consultation Organization, New Delhi, India. pp: 49-82. 